\title{
Immunolocalization of MP84 in renal biopsy sections of sickle cell nephropathy patients
}

\author{
College of Health Sciences, Bahrain
}

$\mathrm{N}$ ephropathy may develop in patients with sickle cell disease and, characterized by proteinuria and predominantly glomerular lesions, has not been as extensively studied as renal tubular alteration in sickle cell disease. ${ }^{1}$ Many factors could play an important role in the pathogenesis of the disease. It has been shown that $25 \%$ of patients with sickle cell disease have proteinuria and the glomerular capillary hypertension may be a pathogenic factor in sickle cell nephropathy. ${ }^{2}$

This is the first study of immunolocalization of MP84 in biopsy sections of three patients with sickle cell nephropathy using alkaline phosphate anti-alkaline phosphate staining (APAAP). MP84 is a novel protein synthesized in response to all cytokines. The antigen is expressed only in stimulated mesangial cells. This protein is virtually specific to stimulated mesangial cells and diseased kidney secions. ${ }^{3-7}$ It is synthesized de novo within 30 minutes of administration of II- 1 to cultured mesangial cells, whether cycling or arrested. It has been shown that MP84 is expressed in red blood cells of renal transplant recipients. ${ }^{8,9}$

The present study showed strong staining of MP84 in mesangial matrix, interstitium and tubules, while other cells were less stained for MP84. This pattern of staining is different than that reported by Mukhtar ${ }^{3}$ of weak staining of tubules and interstitium. The pattern of staining could indicate strong staining of MP84 in

\section{Address for correspondence: \\ Ahmed Mukhtar \\ College of Health Sciences \\ P.O. Box 12 - Bahrain}

glomerular deposition and secretion in cases of sickle cell nephropathy.

\section{REFERENCES}

1. Tejani A, Phadeke K, Adamson O, Nicastri A, Chen CK, Sen D. Renal lesions in sickle cell nephropathy in children. Nephron 1985;39(4):352-5.

2. Falk RG, Schienman J, Philips G, Orringer E, Johnson A, Jenette JC. Prevalence and psthologic features of sickle cell nephropathy and response to inhibition of angiontensin-converting enzyme. N Eng J Med 1992, April 2; 326(14):910-5.

3. Mukhtar A. Study of glomerularulonephritis using monoclonal antibodies against mesangial matrix. $\mathrm{PhD}$ Thesis. University of Aberdeen 1992.

4. Mukhtar A. MP84 expression in pyelonephritis and hydronephrosis kidney biopsy sections. Accepted for publication in Minerva Urologica 1995.

5. Mukhtar A, Al Arrayyed A. MP84 expression in biopsy sections of patients with benign and malignant tumors. Hamdard Medicus. 1994; Vol XXXVII, No 4:5-7.

6. Mukthtar A. Effect of Cyclohexamide, tunicamycin and actinomycin D on MP84 expression by mesangial cellas. Hamdard Medicus. 1995; Vol XXXVIII, No 3:48-51.

7. Power DA, Mukhtar A, Jones MC. Mesangial cells and extracellullar matrix. A Forefront in Nephrology, International Society of Nephrology. Germany: June 9-12, 1991.

8. Mukhtar A. Interleukin-1 excretion in urine specimens of renal transplant recipients with acute rejection using dotblot assay. Accepted for publication in Renal Failure. 1996.

9. Mukhtar A. MP84 expression in red blood cells of renal transplant recipients. Sent for publication 1996. 